Józef Pochwat MS ${ }^{1}$

Międzyzakonne Formacyjne Studium Teologiczne w Krakowie

\title{
Specyfika głównych ośrodków życia monastycznego w Galii w IV i V wieku
}

W wieku IV i V istniało przekonanie, że mnisi są kontynuatorami życia pierwszej gminy apostolskiej ${ }^{2}$. Często odwoływano się do Orygenesa, który już w III wieku stwierdzał, że męczeństwo krwawe i życie ascetyczne zakładają oderwanie od świata, kontemplację po to, aby doskonale zjednoczyć się z Chrystusem³. Monastycyzm zrodził się na Wschodzie i prawie wiek później został zaszczepiony na Zachodzie. Szczególnie zaś dobrze przyjął się w rzymskiej Galii.

Podejmuję omówienie monastycyzmu galijskiego, ponieważ jest on o wiele mniej znany niż monastycyzm Wschodu - mam na myśli Egipt, Palestynę, Kapadocję, Syrię. Taki stan rzeczy był spowodowany dużą ilością materiałów źródłowych na Wschodzie, w przeciwieństwie do skąpej

1 Józef Pochwat MS - urodzony w 1960, kapłan od 1986, dr hab., absolwent patrologii w Instytucie Teologii Dogmatycznej na Wydziale Teologicznym Uniwersytetu Papieskiego Jana Pawła II w Krakowie. Autor publikacji naukowych, popularnonaukowych, tłumacz, wykładowca, kapelan Sióstr Matki Bożej Miłosierdzia w Sanktuarium Bożego Miłosierdzia w Krakowie-Łagiewnikach. Ostatnio wydał: La Salette w świetle dokumentów źródłowych i magisterium Kościoła, Kraków 2016; Kościót św. Faustyny, Kraków 2016; Pelagiusz, Pisma, Kraków 2017; Sulpicjusz Sewer, Kroniki, Kraków 2017 (Źródła Monastyczne, 79). E-mail: jotpe67@wp.pl.

2 J. Pochwat MS, „Misterium iniquitatis”. Studium tajemnicy nieprawości $w$ dziełach Jana Kasjana (360-435), Kraków 2012, s. 40, przyp. 94.

3 D. Olszewski, Dzieje chrześcijaństwa w zarysie, Katowice 1983, s. 42-45. 
liczby tekstów nawiązujących do monastycyzmu w Galii. W ostatnich pięćdziesięciu latach ukazało się kilka znaczących monografii, które pozwalają na bliższe zapoznanie się ze specyfiką monastycyzmu galijskiego. Pierwszy propagator monastycyzmu w Galii, św. Marcin z Tours, nadał ton monastycyzmowi w Galii na długie lata, bo praktycznie do epoki średniowiecznej. Dlatego w Galii nie było czymś wyjątkowym, że mnich zostawał biskupem.

Monastycyzmowi zachodniemu poświęcano mniej miejsca, jest do niego mniej źródeł i dlatego był trudniejszy do zbadania. Ostatnio jednak doczekał się on wielu interesujących publikacji .

Pojawienie się ideału cenobitalnego-mniszego często wiąże się z kierunkami ascetycznymi, które dotarły do Galii w V wieku i propagowane były przede wszystkim w żywocie św. Marcina pióra Sulpicjusza Sewera 5 .

4 Np.: M. Starowieyski, Początki monastycyzmu zachodniego, „Warszawskie Studia Teologiczne”, t. 1, Warszawa 1983, s. 258-283 (zwł. s. 265-268); M. Bielawski, Wstęp, w: Żywoty ojców jurajskich, tłum. zbior., wstęp M. Bielawski, oprac. i red. M. Starowieyski, Kraków 1993, s. 11-26 (Źródła Monastyczne, 1); M. Kanior, Historia monastycyzmu chrześcijańskiego, t. 1: Starożytność (III-VIII w.), Kraków 1993, s. 29; V. Desprez, Początki monastycyzmu. Dzieje monastycyzmu chrześcijańskiego do Soboru Efeskiego (431), Kraków 1999 (Źródła Monastyczne, 21,22 ). Nowszą i pełniejszą analizę monastycyzmu podaje A. Guillaumont, U źródeł monastycyzmu chrześcijańskiego, tłum. S. Wirpszanka, t. 1, 2, Kraków 2006 (Źródła Monastyczne, 37, 38); D. J. Chitty, A pustynia stała się miastem. Wprowadzenie do dziejów monastycyzmu w Egipcie i Palestynie pod panowaniem chrześcijańskim, tłum. T. Lubowiecka, Kraków 2008 (Źródła Monastyczne, 45); W. Harmless, Chrześcijanie pustyni. Wprowadzenie do literatury wczesnego monastycyzmu, tłum. M. Höffner, Kraków 2009, s. 479-530; D. Kasprzak, Życie monastyczne jako podążanie wąską drogą postuszeństwa, w: Fructus Spiritus est Caritas. Księga jubileuszowa ofiarowana ks. prof. F. Drączkowskiemu, red. M. Wysocki, Lublin 2011. O monastycyzmie galijskim: R. Lorenz, Die Anfänge des abendländischen Mönchtum im 4. Jahrhundert, „Zeitschrift für Kirchengeschichte" 75 (1966); E. Griffe, S. Martin et le monachisme gaulois, w: S. Martin et son temps. Mémorial du XVIe centenaire des débuts du monachisme en Gaule, Rome 1961(Studia Anselmiana, 46) E. Griffe, Gaule chrétienne, t. 1-3, Paris 1964-1966; G. M. Colombás, El monacato primitivo, t. 1-2, Madrid 1973; R. Metz, Les vierges chrétiennes en Gaule au IVeme siècle, w: S. Martin et son temps..., dz. cyt., s. 109-132. Na temat monastycyzmu kobiet, zob. A. de Vogüé, Histoire littéraire du mouvement monastique dans l'antiquité, Paris 1991, s. 144-150 (Patrimoines-Christianisme); E. Wipszycka, Ascetyzm kobiecy w Egipcie późnoantycznym: problemy źródłoznawcze i rzeczywistość, w: Chrześcijaństwo u schyłku starożytności. Studia źródłoznawcze, pod red. T. Derdy, E. Wipszyckiej, t. 3, Kraków 2000, s. 245-291.

5 Por. S. Piekarczyk, Barbarzyńcy i chrześcijaństwo. Konfrontacje społecznych postaw $i$ wzorców u Germanów, Warszawa 1968. Na temat początków monastycyzmu na Zachodzie zob.: Starożytne reguły zakonne, tłum. zbior., wybór, wstępy, oprac. M. Starowieyski, oprac. red. 
Pierwszym najpoważniejszym teoretykiem duchowości chrześcijańskiej był Orygenes († 254). Nie był on wprawdzie mnichem, ale położył fundament pod teologię uprawianą w duchu monastycznym. Jako pierwszy z ojców i pisarzy Kościoła napisał o „anachorezie duchowej”, polegającej na odsunięciu się od życia „świeckiego”, to znaczy od „pożądań doczesnych i cielesnych" w tym celu, aby oddać się całkowicie Bogu i rozważaniu słowa Bożego. Celem teologii było wielbienie Boga, do którego prowadziła medytacja Biblii i kontemplacja. Teologia w środowisku monastycznym była synonimem kontemplacji i mistycznego doświadczenia Boga. Podobną rolę spełniała filozofia rozumiana jako studium cnót i praktyka mądrości, czyli życie według zasad ascetycznych.

Zgłębianie Pisma Świętego, kontemplacja i życie ascetyczne miały pomagać mnichowi w walce $\mathrm{z}$ szatanem ${ }^{6}$. Mnich musiał rozpoznać taktykę i metody działania szatana, aby móc zastosować odpowiednio skuteczne środki obronne przeciw jego napaściom. Mnisi podejmujący świadomie tę walkę musieli być także odpowiednio do niej wyposażeni. $\mathrm{Na}$ wzór żołnierzy rzymskich potrzebowali do walki z przeciwnikiem skutecznego oręża. Jednakże nie chodziło o hełm, zbroję i miecz, gdyż walka mnicha z szatanem odbywała się przede wszystkim na poziomie duchowym, a nie cielesnym (por. Ef 6, 11-18).

Mnisi z dobrą znajomością Pisma Świętego dobrze wiedzieli, że właściwą bronią wobec księcia ciemności są wiara, miłość i nadzieja. Ogromną rolę w tej walce pełniła praktyka wyjawiania myśli drugiej osobie, ponieważ szatan traci swoją moc, gdy myśli stają się jawne. Dopóki bowiem

E. Stanula, Warszawa 1980 (Pisma Starochrześcijańskich Pisarzy, 26); M. Starowieyski, Początki monastycyzmu zachodniego, dz. cyt.; M. Kanior, Historia monastycyzmu chrześcijańskiego, t. 1, dz. cyt.

6 Więcej na ten temat zob.:J. Pochwat MS, Nauka o szatanie i demonach w ujęciu Sulpicjusza Sewera, „Polonia Sacra” 16 (34) 2012, nr 31 (75), s. 199-215; J. Pochwat MS, Synteza tematyki opętania i egzorcyzmu w dziełach Sulpicjusza Sewera, ,Tarnowskie Studia Teologiczne” 31 (2012), z. 1, s. 111-120; J. Pochwat MS, Zagadnienie nawrócenia i pokuty w dziełach Sulpicjusza Sewera, „Polonia Sacra” 17 (2013), nr 1 (32), s. 231-239, J. Pochwat MS, „Misterium iniquitatis”..., dz. cyt.; A. Nocoń, Władza złych duchów nad człowiekiem według Jana Kasjana, „Vox Patrum” 33 (2013), t. 59, s. 197-208; J. Pochwat MS, Zło i grzech w nauczaniu Sulpicjusza Sewera, „Vox Patrum" 34 (2014), t. 62, s. 443-456. 
człowiek ukrywa swój grzech, szatan nad nim panuje, natomiast wyznanie grzechu niszczy jego kryjówkę ${ }^{7}$.

W IV i V wieku praktyka „wyjawiania myśli”, chociaż przypominała dzisiejszą spowiedź, różniła się od niej znacząco ${ }^{8}$. W Kościele wciąż praktykowana była pokuta publiczna, która już w III wieku osiągnęła formę rytualną. Maria Jaczynowska zaznacza, że w IV wieku spowiedź miała charakter publiczny, ponieważ nie znano jeszcze spowiedzi indywidualnej, jakkolwiek czasem korzystano z porady kapłana' ${ }^{9}$. Mnisi zatem cenili broń przeciw szatanowi, jaką są pokora, zadośćuczynienie, ubóstwo i zachowywanie cnót. Orężem niezbędnym była modlitwa, rozważanie Pisma Świętego, bojaźń Boża, praktykowanie postu, czuwań, uczynków miłosierdzia, uczestnictwo we Mszy Świętej itp.

Wiek IV i V to również problemy z herezjami, a także różnice w podejściu do zasad samego życia monastycznego. Różniło się ono na Wschodzie i Zachodzie. Ze Wschodu docierały napięcia związane z pelagianizmem ${ }^{10}$ i nestorianizmem ${ }^{11}$, a na Zachodzie pojawił się pryscylianizm. W Galii odbył się synod w Arles w roku 314, zwołany przez

7 Por. J. Pochwat MS, „Misterium iniquitatis”..., dz. cyt., s. 301.

8 J. Pochwat MS, „Misterium iniquitatis”..., dz. cyt., s. 302-303.

9 Por. M. Jaczynowska, Dzieje Imperium Romanum, Warszawa 1995, s. 430.

10 Na temat pelagianizmu por. J. M. Szymusiak, M. Starowieyski, Słownik wczesnochrześcijańskiego piśmiennictwa, t. 2, Poznań 1971, s. 322-323; M. Simon, Cywilizacja wczesnego chrześcijaństwa I-IV w., tłum. E. Bąkowska, Warszawa 1979, s. 292; E. Rebillard, Quasi funambuli: Cassien et la controverse pélagienne sur la perfection, „Revue des Études Augustiniennes” 40 (1994), s. 197-210; J. Śrutwa, Studia z dziejów Kościoła w starożytności, Lublin 1999, s. 123-131; H. Chadwick, Kościół w epoce wczesnego chrześcijaństwa, tłum. A. Wypustek, Warszawa 2004, s. 224-234; R. Toczko, Święty Augustyn - Mowa 348a Przeciw Pelagiuszowi (Contra Pelagium), „Vox Patrum” 30 (2010) t. 55, s. 859-881; R. Toczko, Heretic as Bad Rhetorician: How Augustine Discredited Pelagius, "Augustinian Studies” 42 (2011), s. 211-231; R. Toczko, Pelagiusz widziany oczami św. Augustyna, św. Hieronima, Pawła Orozjusza i Mariusza Wiktoryna, „Vox Patrum” 32 (2012) t. 57, s. 699-712; Pelagiusz, Pisma, tłum. A. Smaroń i J. Mrukówna, wstęp i oprac., J. Pochwat MS, Kraków 2017.

11 Na temat nestorianizmu por. J. M. Szymusiak, M. Starowieyski, Słownik wczesnochrześcijańskiego piśmiennictwa, dz. cyt., s. 289-291. Herezję Nestoriusza szeroko omawia A. Żurek w artykule: Tajemnica Wcielenia w galijskiej literaturze V wieku na przykładzie Jana Kasjana, „Vox Patrum” 20 (2000) 38-39, s. 267-279; o Nestoriuszu zob. C. V. Manzanaves, Pisarze wczesnochrześcijańscy I-VII w. Mały słownik, Warszawa 2001, s. 139; E. Artemi, The Christological Controversy between Nestorius of Constantinople and Cyril of Alexandria, „Vox Patrum” 32 (2012) t. 57, s. 35-51. 
cesarza Konstantyna Wielkiego, który zajął się donatyzmem szerzącym się w północnej Afryce ${ }^{12}$. Synod w Bordeaux (384-385) skierowany był przeciw Pryscylianowi i Instancjuszowi ${ }^{13}$. W ostatnich latach pojawiło się kilka prac na te tematy, uzasadnione wydaje się więc podjęcie tego zagadnienia i wzbogacenie go o aktualny stań badań.

Temat ujmuję w czterech punktach i omawiam główne ośrodki monastyczne Galii w Lerynie, Marsylii, Primuliacum (Tuluza) i Jurze Galijskiej, czyli tzw. ojców jurajskich. Sprecyzowanie tożsamości tych ośrodków jest ważne z punktu widzenia rozumienia dalszych losów monastycyzmu w Kościele zachodnim.

\section{Leryn}

Już na początku wieku V w Galii utworzono dwa mocne ośrodki życia monastycznego: w Lerynie i Marsylii. Chronologicznie pierwszy był założony przez św. Honorata ( $† 430$ ) klasztor na wyspie Leryn ${ }^{14}$. Honorat, podobnie jak Paulin z Noli i Sulpicjusz Sewer, pochodził z gallo-rzymskiej

12 Na temat donatyzmu por. J. M. Szymusiak, M. Starowieyski, Słownik wczesnochrześcijańskiego piśmiennictwa, dz. cyt., s. 123-124.

13 Na temat pryscylianizmu por. J. M. Szymusiak, M. Starowieyski, Słownik wczesnochrześcijańskiego piśmiennictwa, dz. cyt., s. 338-341. Dłuższy opis powstania i rozwoju pryscylianizmu znajduje się w Dialogu III Sulpicjusza Sewera, zob. Sulpicjusz Sewer, Pisma o św. Marcinie z Tours, Żywot, Listy, Dialogi, przekł. P. J. Nowak, wstęp, komentarz i oprac. M. Starowieyski, Kraków 1995, s. 191-198 (Źródła Monastyczne, 8) [aneks 1: Powstanie i rozwój pryscylianizmu]; także na ten temat zob. M. Starowieyski, Początki monastycyzmu zachodniego, dz. cyt., s. 281 [Początki pryscylianizmu]. Przy okazji przedstawienia wydarzeń związanych z historią powstania pryscylianizmu Sulpicjusz Sewer pisze m.in. o herezji, magii, niegodnym zachowaniu wielu biskupów, gwałcie, aborcji, łapownictwie, nocnych schadzkach z nieobyczajnymi kobietami; P. Szczur, Pryscylian, w: Powszechna encyklopedia filozofii, t. 8, red. A. Krąpiec i in., Lublin 2007, s. 517-519; P. Szczur, Pryscylianizm, w: Powszechna encyklopedia filozofii, t. 8, dz. cyt., s. 519-520; K. Sordyl, Dzieje schizmy pryscyliańskiej (370-385). Dramatyczna likwidacja pryscylianizmu, w: Zło w człowieku, Kościele i świecie według Ojców Kościoła, „Vox Patrum” 33 (2013) t. 59, s. 317-327; K. Sordyl, Pryscylianizm. Teologia i historia, Kraków 2015 ; Sulpicjusz Sewer, Kroniki, przeł. P. J. Nowak OFM, wstęp i oprac. J. Pochwat MS, Kraków 2017, s. 345-360 (Źródła Monastyczne, 79).

14 Leryn nosi dzisiaj nazwę: wyspa św. Honorata. O kulturze leryńskiej por. D. Courcelle, Revue des études latines 1968, s. 379-409. 
arystokracji. Już jako młodzieniec oddawał się ascezie i zachęcił do niej swego brata Wenancjusza. Obaj zamierzali udać się na pustynię, ale zamiar ten się nie powiódł. Wenancjusz zmarł w Grecji, a Honorat powrócił przez Italię do Galii. Za radą biskupa Leoncjusza z Fréjus osiedlił się w roku 410 na bezludnych wówczas wyspach Lerynu, 4 km od dzisiejszego Cannes na Lazurowym Wybrzeżu. Tutaj oddał się rozważaniu Pisma Świętego i modlitwie oraz umartwieniom ciała, prowadząc życie chrześcijańskiego anachorety. Podobnie jak w przypadku św. Antoniego († 356) Honorat, żyjąc w odosobnieniu, stał się postacią znaną i szybko znalazł naśladowców. Urodził się prawdopodobnie około 360 roku w okolicach Trewiru, w rodzinie arystokracji gallo-rzymskiej. Jego ojciec był konsulem cesarskim. Honorat przygotował się do chrztu już w młodzieńczym wieku, a jego przyjęcie było samodzielną decyzją. Przyjął chrzest jako wezwanie do życia doskonałego, co spotkało się z niechęcią ze strony jego rodziny, szczególnie ojca, który marzył o wielkiej karierze publicznej dla syna. Wkrótce za jego przykładem poszedł starszy brat Wenancjusz, podejmując życie konwersa i rywalizując z Honoratem w surowości praktyk ascetycznych ${ }^{15}$. Rozróżnienie między mnichami a konwersami jest trudne, gdyż sposób życia obu grup był bardzo podobny. Według pewnych autorów gallo-rzymskich konwers tym różnił się od mnicha, że mógł się ożenić i zatrzymać u swego boku żonę jak siostrę, poprzestać na ubiorze skromnym i ubogim, ale nie nosił pallium, czarnego ubioru mnicha. Winien tworzyć rodzinę ascetyczną i pobożną, ale nie musiał mieszkać w monasterze, nie musiał być oddzielony od świata i wszystkich spraw ziemskich. Jako doskonały przykład społeczności owych konwersów gallo-rzymskich może służyć rodzina duchowa uczniów zgromadzona wokół Sulpicjusza Sewera w jego wiejskiej posiadłości Primuliacum czy wokół Paulina z Noli.

Obaj bracia, Honorat i Wenancjusz, zapragnęli porzucić życie w świecie i odejść na pustynię, rozdali więc swoje dobra ubogim i prowadzeni przez bardziej doświadczonego Kaprazjusza udali się na Wschód, docierając

15 O życiu św. Honorata zob. Hilary z Arles, Vita S. Honorati, wyd. i fr. tłum. M. D. Valentin, Hilaire d'Arles: Vie de saint Honorat, Paris 1977 (Sources Chrétiennes, 235); V. Desprez, Poczatki monastycyzmu..., dz. cyt., s. 267, przyp. 40. 
do Nitry i Skestis. W czasie drogi powrotnej w południowej Grecji zmarł Wenancjusz, zaś Honorat z Kaprazjuszem wrócili do południowej Galii, gdzie biskup Leoncjusz zaproponował im prowadzenie życia pustelniczego na należącej do jego diecezji wyspie Leryn. Początkowo panowały tam ideały koptyjskiego i wschodniego eremityzmu, ale z czasem warunki życia i ideały ewangeliczne skłoniły Honorata i jego towarzyszy do rozpoczęcia życia wspólnego, czego świadectwem jest pierwsza reguła leryńska. Gdy w roku 410 Alaryk forsował Rzym, wyspa była już kolonią pustelników, którym nieformalnie przewodził Honorat. Wybudowano tam klasztor, w którym prowadzono formację mężczyzn chcących żyć według zasad życia monastycznego. Obok tego klasztoru i w łączności $\mathrm{z}$ nim powstała wzorowana na laurach wschodnich kolonia anachoretów. Leryn stał się centrum życia monastycznego i ośrodkiem solidnej formacji chrześcijańskiej oddziałującym na całą Galię. Formację duchową, teologiczną i intelektualną zawdzięczali Lerynowi praktycznie wszyscy biskupi i teologowie tego i późniejszego okresu - Faustus z Riez (ok. $\dagger 495)$, Wincenty z Lerynu (przed † 450), Salwian z Marsylii (ok. † 480), Cezary z Arles († 542/3) i inni ${ }^{16}$. W dużej mierze biskupi i wspólnoty monastyczne przejęli funkcje polityczne i kulturalne ${ }^{17}$.

Wspólnota cenobityczna w Lerynie była oparta na wschodnich ideałach anachoreckich i przynajmniej część starszych mnichów mieszkała w osobnych celach (cellulae), o których istnieniu wspomina także Eucheriusz († 450), chwaląc przeszczepienie do Galii obyczajów koptyjskich i wschodnich. Na początku adept życia monastycznego był formowany, żyjąc we wspólnocie, we wspólnym budynku. Doskonałość nowicjusza polegała na okazaniu uległości we wszystkim starcowi wyznaczonemu przez opata. Po okresie próby, którego czasu trwania nie znamy, mnich składał przyrzeczenie życia zakonnego oraz zmieniał imię i strój. Mnisi żyli w posłuszeństwie wobec opata, który odwiedzał ich i odbywał

16 Por. J. Pochwat MS, Sprawiedliwość i miłosierdzie. Studium „Kazań do ludu” św. Cezarego z Arles, Kraków 2008; J. Pochwat MS, Św. Cezary z Arles ijego czasy, w: św. Cezary z Arles, Kazania doludu, przekł. kazań 1-55 S. Ryznar, przekł. kazań 56-80 J. Pochwat MS, Kraków 2011, s. 7-32 (Źródła Myśli Teologicznej, 57).

17 Por. J. Fontaine, Chrześcijańska literatura łacińska. Rys historyczny, tłum. J. Słomka, Tarnów 1997, s. 155-156. 
z nimi regularne rozmowy. W sobotę i w niedzielę wszyscy spotykali się we wspólnym domu na uroczystej liturgii niedzielnej, nauce duchowej i wspólnotowym posiłku. Główne zasady życia były zgodne z dotychczasową tradycją monastyczną: posłuszeństwo i pokora, ubóstwo osobiste i praca fizyczna, wstrzemięźliwość, przedłużone posty i inne umartwienia, lektura, modlitwa i czuwania nocne. Zgodnie ze zwyczajem tamtej epoki fundator określał zasady obserwancji, zapewne podobnie uczynił Honorat.

Cechy duchowości leryńskiej: ideał świętego to asceta, który głęboko przeżywa swe powołanie do samotności i wyrzeczenia, ale czyni to bez ostentacji i przesady. Święci leryńscy nie czynili cudów, ich autentyczna świętość nie potrzebowała potwierdzenia poprzez niezwykłe znaki; wręcz przeciwnie, starali się ją ukryć, aby być ocenianymi jedynie przez Boga. Dla mnicha leryńskiego wejście do eremu było aktem wyzwolenia, który owocował zdobyciem pokoju wewnętrznego, sprawiającego, że jego sytuacja była podobna do sytuacji aniołów.

W Lerynie rzadko poruszany był temat wojny lub ucieczki od służby wojskowej, ale równocześnie została tam przezwyciężona powszechna u wcześniejszych autorów monastycznych, takich jak np. Hieronim († 419), Sulpicjusz Sewer († 420) czy Paulin z Noli († 431), niechęć do obowiązków wojskowych. Według leryńczyków życie monastyczne nie jest militia caelestis rozumiana jako alternatywa czy opozycja w stosunku do militia Caesaris, przyszli oni bowiem do życia monastycznego w okresie najgłębszej nocy barbarzyńców i dostrzegali konieczność służby wojskowej. Taka postawa owocowała większą skłonnością do pośrednictwa między ascezą a porządkiem doczesnym, co harmonizuje z innymi aspektami duchowości leryńskiej, skłonnej do równowagi i starającej się odrzucać z tradycji monastycznej wszystko to, co było przesadne, prymitywne, grubiańskie. W efekcie Leryn wypracowywał arystokratyczny model mnicha.

Leryńskiej koncepcji duchowości towarzyszył wieloraki optymizm. Pierwszy jego aspekt polegał na poczuciu zaspokojenia psychologicznego i duchowego, które pochodziło z przeświadczenia, że osiągnięto stan doskonałości we wspólnocie doskonałych. Równocześnie znaczące jest to, że w Lerynie nie występował model apostolski (tj. pierwotnej 
gminy apostolskiej), z którego przecież monastycyzm wschodni uczynił idealny wzorzec swych pierwszych doświadczeń tak pustelniczych, jak i cenobitycznych.

Drugim aspektem tego optymizmu było przeżywanie życia monastycznego jako czegoś ciągłego i absolutnie harmonijnego. Mnich leryński nie był przedstawiany jako ktoś, kto ćwiczył się w cnocie i był zaangażowany w proces ciężkiego i powolnego doskonalenia. Asceta, który wchodził do pustelni, od razu odnajdował Chrystusa i stawał się świątynią Boga, a ponieważ realizował w sobie doskonałość chrześcijańską mocą charyzmatów pustelni, korzystał zawsze z łask właściwych niewinnemu Adamowi i wiernym Starego Przymierza oraz z dobrodziejstw nowej konsekracji uczynionej przez Chrystusa. Dlatego też odległa była dla niego możliwość popełniania grzechów. Doskonała cnota nie była uważana za przywilej nielicznych, ale za ozdobę wszystkich.

Trzecim aspektem fundamentalnego optymizmu leryńczyków było to, że w znacznej mierze ich koncepcja życia monastycznego zasadzała się na kontemplacji, jednak bez osiągnięcia wymiaru dojrzałej doktryny mistycznej. Odrzucenie intensywnej ascezy (jako instrumentum satisfactionis) i pominięcie modelu apostolskiego (jako utopijnej oznaki dawnej doskonałości) spotykały się z ideą kontemplacji, urzeczywistniającej stan doskonałej, najwyższej szczęśliwości.

Nowością na polu życia monastycznego byli tzw. konwersi, którzy mając żony, żyli we wstrzemięźliwości seksualnej, nie nosili ubioru mnicha i nie byli zobowiązani do życia w monasterze. Mnisi leryńscy przeszli od ideałów koptyjskiego i wschodniego eremityzmu do życia wspólnotowego z wypracowaniem własnej reguły. Leryn stał się „kuźnią” biskupów w Galii. Mnich leryński dążył do zdobycia pokoju wewnętrznego, co miało imitować życie na wzór aniołów. Mnichów leryńskich charakteryzowała wysoka kultura bycia i troska o dobra kultury niszczone przez barbarzyńców. Dla leryńczyków religia była ważniejsza niż etyka, religii przyznawali pierwszeństwo. 


\section{Marsylia}

Drugim ośrodkiem życia monastycznego była Marsylia, gdzie po doświadczeniach z pobytu na pustyni egipskiej mnich Jan Kasjan około roku 415 założył dwa klasztory - męski i żeński. Jego program odegrał znaczącą rolę w rozwoju życia monastycznego w Lerynie. Kasjan za pomocą dyscypliny egipskiej próbował przezwyciężyć galijski marazm, a duchowość oparł na surowej ascezie w celu osiągnięcia doskonałości moralnej, co wiązało się z pokonywaniem grzechów i grzesznych skłonności, by dojść do życia kontemplacyjnego, czyli zjednoczenia z Bogiem. Pierwszy etap tego życia, czyli zwalczanie grzechów i zdobywanie cnót, był według Kasjana zasadniczym celem życia klasztornego ${ }^{18}$.

Monastycyzm galijski, którego początki były późniejsze od monastycyzmu rozwijającego się na Wschodzie, wykazuje na przełomie IV i V wieku spore zróżnicowanie. Byli bowiem pustelnicy i dziewice żyjący pojedynczo (nawiązanie do anachoretycznego stylu życia), jak również mnisi i mniszki żyjący w mniej lub bardziej zorganizowanych grupach (nawiązanie do cenobitycznego stylu życia). Funkcjonowały klasztory pustelników, pustelniczo-misjonarskie i typu miejskiego. Klasztory znajdowały się głównie w miastach, ale można je było spotkać także we wsiach koło kościołów parafialnych. Pustelnicy na miejsce swego pobytu, ponieważ nie mieli do dyspozycji pustyni, wybierali ogromne puszcze i lasy, niedostępne wybrzeża albo wyspy, miejsca niełatwe do zamieszkania, gdzie trudno było spotkać innych ludzi ${ }^{19}$.

Jan Kasjan należy do grona mnichów, którzy chcieli przeszczepić bogactwo i ideały monastycyzmu Kościoła wschodniego do Kościoła zachodniego, jednak jego nauki wśród mnichów łacińskich zostały przyjęte dopiero wiek później. Jednym z powodów tego stanu rzeczy była nauka

18 Por. H. I., Marrou, Jean Cassien à Marseille, „Revue du Moyen Âge Latin” I (1945), s. 5-26; H. I., Marrou, Le fondateur de Saint-Victor à Marseille: Jean Cassien, „Province Historique” 16 (1966), s. 297-308; V. Desprez, Poczatki monastycyzmu..., dz. cyt., s. 273; A. Żurek, Życie i działalność Cezarego z Arles, w: Św. Cezary z Arles, oprac. i wybór tekstów A. Żurek, Kraków 2002, s. 32, przyp. 43 (Ojcowie Żywi, 17).

19 Por. M. Starowieyski, Początki monastycyzmu zachodniego, dz. cyt., s. 268; J. Kłoczowski, Wspólnoty chrześcijańskie, Kraków 1964, s. 70-73. 
ascetyczna, którą przejął od ojców pustyni i od Ewagriusza z Pontu († 399). Do mnichów galijskich docierał spór dotyczący łaski toczący się pomiędzy Augustynem a pelagianami, spór, który poruszał Prowansję (Marsylię i Leryn) już wcześniej, zanim powstały pisma monastyczne Jana Kasjana.

Jan Kasjan zauważył, że w dziele zbawienia Augustyn († 430) przeakcentowuje rolę łaski, natomiast Pelagiusz (†420) przeakcentowuje w nim rolę człowieka. Kasjan nie podjął bezpośredniej polemiki z Augustynem czy Pelagiuszem. On sam naukę na ten temat zawarł głównie w Collationes Patrum. Należy podkreślić reakcję Kasjana, pragnącego uspokoić mnichów, którzy wypowiedzi Augustyna o predestynacji przeciwstawiali zdanie, że „Bóg pragnie, aby wszyscy ludzie zostali zbawieni” (1 Tm 2, 4). Nauka o predestynacji stawiała pod znakiem zapytania sensowność ascetycznych wysiłków mnichów. Kasjan odrzucił naukę o przeznaczeniu, które było zaprzeczeniem powszechnej woli zbawczej Boga. Autorowi Collationes przypisywano pogląd, według którego ludzie mogą zrobić pierwszy krok ku Bogu bez pomocy łaski Bożej. W świetle dzisiejszych badań wiemy, że Kasjan stał się rzecznikiem tych mnichów, którzy nie przyjmowali predestynacyjnego nauczania Augustyna o łasce. Augustyn wydawał się przeczyć ludzkiej wolności, czyli i ascetycznym wysiłkom moralnym. Kasjana oskarżano o to, że w swym nauczaniu na temat relacji pomiędzy łaską i wolnością wyrażał się niejasno. Trzeba jednak pamiętać, że w czasie zażartych sporów wokół nauki Pelagiusza protest Kasjana jest wyrażany z punktu widzenia starszego, bardziej synergistycznego poglądu na te zagadnienia. Poglądu mówiącego o współdziałaniu Boga i człowieka w dziele zbawienia. Jakkolwiek Magisterium Kościoła wyraźnie mówi o „współpracy” człowieka z łaską, synergizm nie tłumaczy właściwie katolickiej nauki o łasce, która mówi, że wolność człowieka w dziele zbawienia sama jest darem łaski Bożej, zarówno co do możności, jak i aktu ${ }^{20}$.

Z całą pewnością Jan Kasjan nie był pelagianinem, skoro utrzymywał, że łaska jest konieczna do osiągnięcia czystości serca i doskonałej miłości. Wydaje się, że z punktu widzenia doktryny Augustyna Kasjan dopuszczał możliwość osiągnięcia jej na dwa sposoby. Chociaż w niektórych

20 Więcej na ten temat zob. J. Pochwat MS, „Misterium iniquitatis”..., dz. cyt., s. 46-48. 
tekstach stwierdza, że ,początek naszej dobrej woli jest darem natchnienia Pańskiego", to inne teksty pokazują, iż jego zdaniem w niektórych przypadkach łaska była dawana tym, „którzy dla jej zdobycia napracowali się i napocili”. Są również badacze, którzy twierdzą, że raczej trudno jest nadal utrzymać pogląd Kasjana, iż ludzie mogą zrobić pierwszy krok ku Bogu bez pomocy łaski Bożej. Wykazują, że uważna lektura jego dzieł pokazuje umiejętność Kasjana zachowania równowagi (synergii) między wolą ludzką i działaniem łaski Bożej. Kasjan nie zawsze jasno twierdził, że zarówno impuls wiary, jak i łaska nawrócenia pochodzą od Boga, czasem przypisywał ją człowiekowi. Przekonanie, że wolna wola człowieka ma w procesie zbawczym przynajmniej iskierkę (scintillam) własnej inicjatywy, niezależnej od łaski Bożej, wyrażało u Kasjana myśl ewidentnie pelagiańską. Właśnie te twierdzenia teologowie z czasem nazwali „semipelagianizmem”. Także nauka Kasjana o zasługiwaniu była częściowo pelagiańska. Kasjan skłaniał się do opinii, że pomimo grzechu pierwszych ludzi człowiek nie utracił całkowicie zdolności rozeznania i czynienia dobra, a w konsekwencji zasługiwania na wieczną nagrodę.

Trzecią kwestią pelagiańską u Kasjana jest wytrwanie w dobrym. Mistrz z Marsylii był tu niekonsekwentny. Raz mówił, że łaska Boża jest niezbędna do wytrwania w cnocie, a innym razem uważał, że nie jest koniecznie potrzebna. To była potrójna niezgodność Jana Kasjana z ustaloną później, na bazie teologii Augustyńskiej, doktryną łaski Bożej i wolnej woli człowieka. Kasjan rzecz jasna nie zdawał sobie sprawy ze swej nieprawowierności w tym względzie. Był tak samo niedokładny w używaniu terminów dotyczących łaski i wolnej woli, jak i terminów odnoszących się do natur w Chrystusie według Nestoriusza ( $†$ 451). Swymi stwierdzeniami fałszywie oskarżył Nestoriusza o bycie gorszym niż diabeł. Tą niekonsekwencją i brakiem precyzji zaszkodził samemu sobie. Kościół odrzucił bowiem poglądy Jana Kasjana na temat łaski i wolnej woli człowieka na synodzie galijskim w Orange w $529 \mathrm{roku}^{21}$. Odrzucenie nauki Kasjana zatwierdził także w 531 roku papież Bonifacy II. Sam termin

21 Zob. Dokumenty synodów od 506 do 553 roku. Synody i Kolekcje Praw, układ i oprac. A. Baron, H. Pietras, Kraków 2014, s. 128-136 (Źródła Myśli Teologicznej, 73). 
„semipelagianie”, wymyślony w XVII wieku, rozciągnięto wtedy na mnichów prowansalskich, w tym i na Jana Kasjana ${ }^{22}$.

W monastycyzmie marsylskim widać zróżnicowanie na klasztory męskie i żeńskie. Ideałem było zwalczanie grzechu i skłonności do niego, by osiągnąć cnoty. Do dziś bardzo ważny jest spór pomiędzy pelagianizmem a augustynizmem oraz pytanie, co jest ważniejsze: dobroć czy świętość. W obu przypadkach nie ma znaku równości i być nie może, natomiast ważna jest należycie ustawiona harmonia. Potrzebne są zarówno łaska Boża, jak i wysiłki człowieka, potrzebna jest dobroć, ale to nie wystarczy, chodzi bowiem o świętość: a zatem łaska Boża przed wysiłkiem człowieka, ale nie bez niego.

\section{Primuliacum (Tuluza)}

Postacią równie ważną dla monastycyzmu galijskiego był żyjący po zachodniej stronie Galii, w Akwitanii, współczesny Janowi Kasjanowi Sulpicjusz Sewer (ok. 360-420) ${ }^{23}$. Spotkanie z Paulinem z Noli i Marcinem z Tours zachęciło go do prowadzenia życia mniszego. Dlatego z kilkoma przyjaciółmi założył klasztor w Primuliacum i prawdopodobnie został wyświęcony na kapłana, ale wiódł życie mnicha pisarza. Był to początek zakonów w Galii: Ligugé, Marmoutiers, Lérins, Marsylia, a w Akwitanii początek okresu świetności.

Sulpicjusz Sewer jest świadkiem przełomu IV i V wieku, dyskretny w kwestiach publicznych, nieoceniony, jeśli chodzi o znajomość kultury i mentalności tej epoki, znający historię herezji na Zachodzie Pryscyliana $(† 385)$ i Ariusza $(† 336)^{24}$.

22 Więcej na ten temat zob. J. Pochwat MS, „Misterium iniquitatis”..., dz. cyt., s. 170, s. $323-327$.

23 Na temat życia Sulpicjusza Sewera zob. J. Pochwat MS, Sulpicjusz Sewer i jego dzieło w czasie przemian dziejowych w Galii na przełomie IV $i$ V wieku, „Teologia Patrystyczna” 8 (2011), s. 65-102.

${ }^{24}$ Zob. Sulpicjusz Sewer, Kroniki, przeł. P. J. Nowak OFM, wstęp i oprac. J. Pochwat MS, Kraków 2017, s. 314-344 (Źródła Monastyczne, 79). 
Sewer osobiście poznał Pryscyliana, surowego ascetę hiszpańskiego, który zebrał wokół siebie ludzi chcących żyć w surowej ascezie. Pryscylian, jak podaje Sulpicjusz w swoim Dialogu Trzecim, pochodził z bogatej rodziny, był elokwentny, oczytany i wykształcony, skory do dyskusji. Cechowały go wybitne zdolności, ale był przewrotny. Potrafił pościć, czuwać, być oszczędny, ale równocześnie pozostawał próżny i pyszny. Człowiek ten, według ówczesnej opinii, ćwiczył się w sztukach magicznych. Pociągnął za sobą wielu ludzi, zarówno bogatych, jak i biednych. Pryscylianowi udowodniono czary, zajmowanie się sprośnymi doktrynami, nocne schadzki z nieobyczajnymi kobietami i fakt, że zwykł modlić się nago. Po straceniu Pryscyliana herezja, której był twórcą, nie tylko nie ustała, ale jeszcze bardziej się rozpowszechniła. Heretycy mieli być schwytani i pozbawieni życia oraz dóbr materialnych.

Sulpicjusz ukazuje także nadużycia przy osądzaniu heretyków, skazywanych na podstawie wyglądu, a nie ze względu na wyznawaną wiarę. Był świadkiem ewidentnego nadużycia, jakiego dopuścili się biskupi, mający pełną świadomość popełnionego zła. Sulpicjusz ukazał mądrość św. Marcina, który chciał ratować od śmierci zarówno chrześcijan, jak i heretyków. Pryscylian wraz z czterema swoimi uczniami został ścięty w Trewirze w 385 roku. Ani św. Marcin, ani św. Ambroży († 397) nie zdołali zapobiec tej egzekucji, a właściwie morderstwu, które należy do rzadkich w starożytności przypadków odwołania się do świeckiego wymiaru sprawiedliwości w sprawie kościelnej. Niechlubną rolę w tej sprawie odegrał biskup Itacjusz, wnosząc oskarżenie, za co został potępiony przez większość biskupów i usunięty z biskupstwa ${ }^{25}$.

25 Dwadzieścia lat temu Marek Starowieyski napisał: „Mimo licznych prac dotyczących Pryscyliana sprawa daleka jest od ostatecznego rozwiązania. Pryscylian, surowy asceta hiszpański, zebrał wokół siebie ludzi chcących żyć w surowej ascezie. Jak się wydaje, nauka jego zawierała liczne rysy zaczerpnięte z manicheizmu i gnozy. Potępiony przez synod w Saragossie (380 rok), udał się do Rzymu, gdzie nie został przyjęty przez papieża Syrycjusza, podobnie potraktował go Ambroży w Mediolanie. Powtórnie potępiony przez synod w Bordeaux w roku 384 odwołał się do cesarza, który skazał go na śmierć, czemu ostro sprzeciwił się Marcin. Po śmierci Pryscyliana, którego nie udało mu się ocalić, starał się uratować przynajmniej jego zwolenników i, by to uczynić, nawiązuje nawet wspólnotę (communio) z biskupami, którzy doprowadzili do skazania Pryscyliana, co sobie do końca życia będzie wyrzucał i po roku 385 nie weźmie udziału w żadnym z synodów galijskich, 
W tej części Galii zarysował się problem, który będzie się pojawiał w różnych odcieniach jako napięcie między monastycyzmem a hierarchią. Innym zagadnieniem jest to, że skazanie na śmierć herezjarchy nie likwiduje herezji, ale jeszcze pomaga w jej rozprzestrzenianiu. Pojawia się pytanie, na ile wyżej omówione konflikty z ich rozwiązaniami miały wpływ na czasy Karolingów.

\section{Jura Galijska}

Dla całościowego obrazu początków monastycyzmu galijskiego należy podać w zarysie główne dane dotyczące tzw. ojców jurajskich, mimo że przekraczają ramy czasowe życia i działalności Sulpicjusza Sewera, gdyż obejmują lata od około 430 do 515 roku. Jura była jedną z prowincji Galii, górzystą, zalesioną i dziką krainą - obecnie stanowi część wschodniej Francji graniczącą z północno-zachodnią częścią Szwajcarii w odległości około 30 km na północny zachód od dzisiejszej Genewy. Początki tzw. ojców jurajskich związane są z trzema imionami: Romanusem, Lupicyniusem i Eugendusem, o których opowiada tekst Żywotów ojców jurajskich ${ }^{26}$. Lektura tego dzieła jest ważna, ponieważ można się w niej doszukać aluzji do innych dzieł monastycznych, takich jak: Żywot św. Antoniego Atanazego († 373), Reguły Pachomiusza († 346) i Bazylego († 379), Listy i Żywoty mnichów Hieronima, Historia mnichów i Historia Kościoła Rufina († 411), Institutiones i Rozmowy Jana Kasjana oraz Żywot św. Marcina i Dialogi napisane przez Sulpicjusza Sewera. Wspólnoty jurajskie rozwijały się i przeobrażały, co było spowodowane wzrostem liczby

by nie spotkać niegodziwych biskupów, co oczywiście dolewało oliwy do oskarżeń Marcina, którego podejrzewano nawet o pryscylianizm" - M. Starowieyski, Święty Marcin i jego biograf, „W Drodze” 11 (1994) 255, s. 71-72. Por. M. Starowieyski, Poczatki monastycyzmu zachodniego, dz. cyt., s. 269-270 i przyp. 80 i 81 oraz s. 281. Dzisiaj nasza wiedza na temat Pryscyliana i jego herezji jest już dostatecznie wyczerpująca, zob. Sulpicjusz Sewer, Pisma..., dz. cyt., s. 191198; Słownik wczesnochrześcijańskiego piśmiennictwa, dz. cyt., s. 338-341; P. Szczur, Pryscylian, dz. cyt., s. 517-519, K. Sordyl, Dzieje schizmy pryscyliańskiej..., dz. cyt., s. 317-327; K. Sordyl, Pryscylianizm. Teologia i historia, dz. cyt.; zob. Sulpicjusz Sewer, Kroniki, dz. cyt. s. 345-360.

${ }_{26}$ Vie des Pères du Jura, ed. F. Martine, Paris 1968, s. 168 (Sources Chrétiennes, 142); por. G. M. Colombás, El monacato primitivo, t. 1-2, dz. cyt.; Żywoty ojców jurajskich, dz. cyt. 
mnichów oraz nawarstwianiem się doświadczeń i tradycji. Wspólnoty jurajskie przeszły od mało formalnej grupy ascetów do zorganizowanej instytucji. Wykształcił się ideał ścisłej klauzury. Bardziej od odważnej i czynnej miłości zaczęły się liczyć we wspólnocie opanowanie i wyrozumiałość. W klasztorze posiłkowi zaczęła towarzyszyć lektura; pojawiła się wspólna sypialnia. Obok wspólnot męskich pojawiła się wspólnota mniszek, której początek dała nieznana z imienia siostra braci Romanusa i Lupicyniusa.

Do głównych cech duchowości i formy monastycyzmu jurajskiego zaliczyć należy: częściową separację od świata, porzucenie ogniska domowego, post, czuwanie, ubóstwo, zaniechanie troski o ubiór itp. Dbano o regularną modlitwę całej wspólnoty i sprawowanie Eucharystii. Ceniono osobiste zaangażowanie modlitewne i wysiłek wkładany w lekturę. Główny akcent położono na dwa elementy. Pierwszym była praca. Traktowano ją poważnie i z dużym zaangażowaniem. Mnisi rozpoczęli karczowanie lasu, a potem uprawę ziemi, stwarzając miejsca pracy i warunki godziwego utrzymania. Oni także rozbudowywali, zagospodarowywali i przemieniali, wraz ze wzrostem potrzeb, klasztorne pomieszczenia. Drugim elementem było położenie silnego akcentu na życie wspólne i miłość bliźniego. Wobec tych wartości topniały i nabierały elastyczności sztywne, zdawałoby się, reguły i przepisy dotyczące ascezy. One także powodowały, że tamtejszą duchowość można nazwać ewangeliczną. Z ojcami jurajskimi pojawia się skłonność do europeizacji monastycyzmu i polemika ze wschodnimi wzorcami chrześcijańskiego ascetyzmu oraz tendencje zmierzające do odnalezienia własnej tożsamości ${ }^{27}$. Następowała też próba odczytania na nowo pism monastycznych Jana Kasjana.

Zarówno Romanus, jak i Lupicynius uznani zostali za świętych, a ich wspomnienie w kalendarzu liturgicznym obchodzi się 28 lutego.

Charakterystycznym rysem wypracowanym przez mnichów jurajskich było położenie akcentu na opanowanie i wyrozumiałość. Mnisi ci podjęli z ogromnym zaangażowaniem pracę, szczególnie karczowanie lasów, dla uzyskania ziemi i zajęcia się jej uprawą. To praktyczne podejście

27 Por. M. Bielawski, Wstęp, w: Żywoty ojców jurajskich, dz. cyt., s. 11-26. 
przyczyniło się do podniesienia kultury agrarnej, a co za tym idzie, dając ludziom miejsca pracy, podniosło ich stopę życiową. Ten sposób życia: ora et labora podjął św. Benedykt († 547), a następnie uczynił to św. Bernard z Clairvaux († 1153).

$$
*^{*} *
$$

Monastycyzm galijski IV i V wieku był ruchem, do którego - podobnie jak na Wschodzie - zgłaszali się zarówno mężczyźni, jak i kobiety, aby praktykować życie oddane tylko Bogu. Ich życie polegało na unikaniu grzechu i pielęgnowaniu cnoty. Ci, którzy tę formę wybrali, robili to bardzo intensywnie i ponosili ogromne koszty, poświęcając wygody normalnego ludzkiego życia - rodzinę, małżeństwo, jedzenie, sen, towarzystwo - i przyjmując surową, ascetyczną dyscyplinę. W Lerynie pojawili się żonaci konwersi, którzy nie korzystali z łoża małżeńskiego. Mnisi leryńscy wypracowali wysoką kulturę, co pozwoliło zachować najcenniejsze rzeczy przed zniszczeniami powodowanymi przez najazdy barbarzyńców. Wydali ze swego grona dużą liczbę biskupów i teologów. W Marsylii mnisi spotykający się z odżywającym aż do naszych czasów sporem: łaska Boża czy wysiłek człowieka, dobroć czy świętość, pokazali, że jedno i drugie jest ważne, ale musi być pomiędzy nimi zachowana należyta harmonia. W Primuliacum działał Sulpicjusz Sewer, który opisał konflikt między monastycyzmem a hierarchią oraz mechanizm rozprzestrzeniania się herezji. Mnisi jurajscy natomiast położyli duży nacisk na pracę, na praktykę życia codziennego, przez co niewątpliwie przyczynili się do podniesienia poziomu życia ludzi. Otwarte jest pytanie, kogo te ośrodki wydały w wieku VII i VIII?

Należy zaznaczyć, że ruch monastyczny w Galii nie był zależny od monastycyzmu egipskiego, przyjmował jedynie ogólne jego założenia. Dopiero od Jana Kasjana zaczął przyjmować założenia egipskie. Kasjan bowiem w De Institutis określił podstawy życia w monastycznej wspólnocie: jak mnisi mają się ubierać, modlić, odnosić do siebie i w jaki sposób formować nowicjuszy. Radził on galijczykom, aby wzorować się na Wschodzie, a przede wszystkim na przykładzie Egiptu. Interesował go głównie rozwój duchowy i twierdził, że koncentrowanie uwagi na cudach było rozpraszaniem się na czymś, co nieistotne. Mogła to być aluzja 
do Żywotu Marcina z Tours Sulpicjusza Sewera, które to dzieło wychwalało cuda dokonane przez założyciela monastycyzmu galijskiego. Sulpicjusz Sewer ukazał św. Marcina, który w jednej osobie połączył funkcje biskupa i mnicha, rzecz dotąd niespotykaną. Zamiast cudów Kasjan przedstawił instituta, czyli „reguły”, które w szerszym kontekście są bliższe określeniu "fundamentalne zasady”. Jako dobry pedagog Kasjan chciał ustanowić monastycyzm, instruując mnichów Zachodu co do metod stosowanych na Wschodzie. Z całą pewnością można stwierdzić, że monastycyzm Wschodu był bardziej ascetyczno-anachorecki, natomiast monastycyzm galijski bardziej apostolsko-ewangelizujący.

Warto zaznaczyć, że ten sam ruch monastyczny różnił się w szczegółach na Wschodzie i Zachodzie. Miał i ma do tego pełne prawo. Warunki klimatyczne, a zwłaszcza mentalność ludzi, miały tutaj przemożny wpływ na podejście do tej samej rzeczywistości. Rozwój monastycyzmu uczy, że należy zawsze się liczyć z warunkami, jakie panują w danym miejscu. W jedności jest miejsce na różnice, które mogą ubogacać, a nie dzielić, nie należy zatem na siłę wszystkiego i wszystkich „ujednolicać”. 


\section{Summary}

Specyfika głównych ośrodków życia monastycznego w Galii w IV i V wieku

Postaciami kluczowymi dla monastycyzmu Galii w IV i V wieku są: św. Marcin z Tours, Sulpicjusz Sewer, Jan Kasjan, Romanus i Lupicynius. Monastycyzm galijski odsłania inne podejście niż zasady wypracowane na Wschodzie. W samej Galii wykazuje również pewne zróżnicowanie.

Monastycyzm Wschodu charakteryzował się tym, że był zdecydowanie ascetycznoanachorecki, w odróżnieniu od monastycyzmu galijskiego o nastawieniu apostolskoewangelizującym. Oba te podejścia wcale się nie wykluczają, wręcz przeciwnie, uczą zasady jedności w różnorodności. Pokazują, że w życiu monastycznym chodzi o praktykowanie życia oddanego Bogu w pełnym jego wymiarze, zarówno duchowym, jak i cielesnym. Jednakże sposób realizacji tych założeń nie musi być wszędzie jednakowy, na szczyt prowadzi bowiem wiele dróg.

Słowa kluczowe: mnich, szatan, pelagianizm, semipelagianizm, pryscylianizm

Specifics of main centres of monastic life

in Gaul in the fourth and five century

The key figures for Gaul's monasticism in the fourth and fifth century are: Martin of Tours, Sulpicius Severus, John Cassian, Romanus and Lupicinius. Monasticism in Gaul reveals a different approach to the principles developed in the East. In Gaul itself, some diversity can be observed.

Monasticism of the East had a strong ascetic-anchoritic character, unlike Gallic monasticism with its apostolic and evangelical attitude. These two approaches do not contradict each other, quite the reverse, they both teach the principles of unity in diversity. They show that monastic life is about practicing a life devoted to God in its full dimension; both spiritually and bodily. The way of putting into practice these principles does not have to be the same. There are many routes leading to the aim.

Keywords: monk, Satan, pelagianism, semi-pelagianism, pryscilianism

\section{Bibliografia}

Artemi E., The Christological Controversy between Nestorius of Constantinople and Cyril of Alexandria, „Vox Patrum” 32 (2012) t. 57, s. 35-51.

Bielawski M., Wstęp, w: Żywoty ojców jurajskich, tłum. zbior., wstęp M. Bielawski, oprac. i red. M. Starowieyski, Kraków 1993 (Źródła Monastyczne, 1). 
Chadwick H., Kościół w epoce wczesnego chrześcijaństwa, tłum. A. Wypustek, Warszawa 2004.

Chitty D. J., A pustynia stała się miastem. Wprowadzenie do dziejów monastycyzmu w Egipcie i Palestynie pod panowaniem chrześcijańskim, tłum. T. Lubowiecka, Kraków 2008 (Źródła Monastyczne, 45).

Colombás G. M., El monacato primitivo, t. 1-2, Madrid 1973.

Courcelle D., Revue des études latines, Paris 1968.

Desprez V., Poczatki monastycyzmu. Dzieje monastycyzmu chrześcijańskiego do Soboru Efeskiego (431), Kraków 1999 (Źródła Monastyczne, 21, 22).

Dokumenty synodów od 506 do 553 roku. Synody i Kolekcje Praw, układ i oprac., A. Baron, H. Pietras, Kraków 2014 (Źródła Myśli Teologicznej, 73).

Fontaine J., Chrześcijańska literatura łacińska. Rys historyczny, tłum. J. Słomka, Tarnów 1997.

Griffe E., Gaule chrétienne, t. 1-3, Paris 1964-1966.

Griffe E., S. Martin et le monachisme gaulois, w: S. Martin et son temps. Mémorial du XVIe centenaire des débuts du monachisme en Gaule, Rome 1961, s. 3-24 (Studia Anselmiana, 46).

Guillaumont A., U źródeł monastycyzmu chrześcijańskiego, tłum. S. Wirpszanka, t. 1, Kraków 2006 (Źródła Monastyczne, 37).

Guillaumont A., U źródeł monastycyzmu chrześcijańskiego, tłum. S. Wirpszanka, t. 2, Kraków 2006 (Źródła Monastyczne, 38).

Harmless W., Chrześcijanie pustyni. Wprowadzenie do literatury wczesnego monastycyzmu, tłum. M. Höffner, Kraków 2009.

Hilary z Arles, Vita S. Honorati, wyd. i fr. tłum. M. D. Valentin, Hilaire d'Arles: Vie de saint Honorat, Paris 1977 (Sources Chrétiennes, 235).

Jaczynowska M., Dzieje Imperium Romanum, Warszawa 1995.

Kanior M., Historia monastycyzmu chrześcijańskiego, t. 1: Starożytność (III-VIII w.), Kraków 1993.

Kasprzak D., Życie monastyczne jako podążanie wąska droga posłuszeństwa według Reguły Eugipiusza, w: Fructus Spiritus est Caritas, Księga jubileuszowa ofiarowana ks. prof. F. Drączkowskiemu, red. M. Wysocki, Lublin 2011, s. 181-195.

Kłoczowski J., Wspólnoty chrześcijańskie, Kraków 1964.

Lorenz R., Die Anfänge des abendländischen Mönchtum im 4. Jahrhundert, ,Zeitschrift für Kirchengeschichte" 75 (1966), s. 1-61.

Manzanaves C. V., Pisarze wczesnochrześcijańscy I-VII w. Mały słownik, Warszawa 2001.

Marrou H. I., Jean Cassien à Marseille, „Revue du Moyen Âge Latin” I (1945), s. 5-26.

Marrou H. I., Le fondateur de Saint-Victor à Marseille: Jean Cassien, „Province Historique" 16 (1966), s. 297-308.

Metz R., Les vierges chrétiennes en Gaule au IVeme siècle, w: S. Martin et son temps, Rome 1961 (Studia Anselmiana, 46).

Nocoń A., Władza złych duchów nad człowiekiem według Jana Kasjana, „Vox Patrum” 33 (2013) t. 59, s. 197-208.

Olszewski D., Dzieje chrześcijaństwa w zarysie, Katowice 1983. 
Pelagiusz, Pisma, tłum. A. Smaroń i J. Mrukówna, wstęp i oprac., J. Pochwat MS, Kraków 2017.

Piekarczyk S., Barbarzyńcy i chrześcijaństwo. Konfrontacje społecznych postaw $i$ wzorców u Germanów, Warszawa 1968.

Pochwat J., „Misterium iniquitatis”. Studium tajemnicy nieprawości w dziełach Jana Kasjana (360-435), Kraków 2012.

Pochwat J., Nauka o szatanie i demonach w ujęciu Sulpicjusza Sewera, „Polonia Sacra” 16 (34) 2012, nr 31 (75), Kraków, s. 199-215.

Pochwat J., Sprawiedliwość i miłosierdzie. Studium „Kazań do ludu” św. Cezarego z Arles, Kraków 2008.

Pochwat J., Sulpicjusz Sewer i jego dzieło w czasie przemian dziejowych w Galii na przełomie IV $i$ V wieku, „Teologia Patrystyczna” 8 (2011), s. 65-102.

Pochwat J., Św. Cezary z Arles i jego czasy, w: Św. Cezary z Arles, Kazania do ludu, przekł. kazań 1-55 S. Ryznar, przekł. kazań 56-80 J. Pochwat MS, Kraków 2011 Źródła Myśli Teologicznej 57.

Pochwat J., Synteza tematyki opętania i egzorcyzmu w dziełach Sulpicjusza Sewera, „Tarnowskie Studia Teologiczne” 31 (2012) 1, s. 111-120.

Pochwat J., Zagadnienie nawrócenia i pokuty $w$ dziełach Sulpicjusza Sewera, „Polonia Sacra" 17 (2013) nr 1 (32), s. 231-239.

Pochwat J., Zło i grzech w nauczaniu Sulpicjusza Sewera, „Vox Patrum” 34 (2014) 62, s. $443-456$.

Rebillard E., Quasi funambuli: Cassien et la controverse pélagienne sur la perfection, „Revue des Études Augustiniennes” 40 (1994), s. 197-210.

Simon M., Cywilizacja wczesnego chrześcijaństwa I-IV w., tłum. E. Bąkowska, Warszawa 1979.

Sordyl K., Dzieje schizmy pryscyliańskiej (370-385). Dramatyczna likwidacja pryscylianizmu, w: Zło w człowieku, Kościele i świecie według Ojców Kościoła, „Vox Patrum” 33 (2013) 59, 317-327.

Sordyl K., Pryscylianizm. Teologia i historia, Kraków 2015.

Starowieyski M., Początki monastycyzmu zachodniego, „Warszawskie Studia Teologiczne" 1 (1983), s. 258-283.

Starowieyski M., Święty Marcin i jego biograf, „W Drodze” (1994) 11 (255), s. 63-74.

Starożytne Reguły Zakonne, tłum. zbior., wybór, wstępy, oprac. M. Starowieyski, E. Stanula, Warszawa 1980 (Pisma Starochrześcijańskich Pisarzy, 26).

Sulpicjusz Sewer, Kroniki, przeł. P. J. Nowak OFM, wstęp i oprac. J. Pochwat MS, Kraków 2017 (Źródła Monastyczne, 79).

Sulpicjusz Sewer, Pisma o św. Marcinie z Tours, Żywot, Listy, Dialogi, przekł. P. J. Nowak, wstęp, komentarz i oprac. M. Starowieyski, Kraków 1995 (Źródła Monastyczne, 8).

Szczur P., Pryscylian, Pryscylianizm, w: Powszechna encyklopedia filozofii, t. 8, red. A. Krąpiec i in., Lublin 2007, s. 517-519.

Szymusiak J. M., Starowieyski M., Słownik wczesnochrześcijańskiego piśmiennictwa, Poznań 1971.

Śrutwa J., Studia z dziejów Kościoła w starożytności, Lublin 1999. 
Toczko R., Heretic as Bad Rhetorician: How Augustine Discredited Pelagius, „Augustinian Studies" 42 (2011), s. 211-231.

Toczko R., Pelagiusz widziany oczami św. Augustyna, św. Hieronima, Pawła Orozjusza i Mariusza Wiktoryna, „Vox Patrum” 32 (2012) t. 57, s. 669-712.

Toczko R., Święty Augustyn - Mowa 348a Przeciw Pelagiuszowi (Contra Pelagium), „Vox Patrum" 30 (2010), 55, s. 859-881.

Vie des Pères du Jura, ed. F. Martine, Paris 1968 (Sources Chrétiennes, 142).

Vogüé A. de, Histoire littéraire du mouvement monastique dans l'antiquité. Première partie: Le monachisme latin. De la mort d'Antoine à la fin du séjour de Jérôme à Rome (356385), Paris 1991.

Wipszycka E., Ascetyzm kobiecy w Egipcie późnoantycznym: problemy źródłoznawcze irzeczywistość, w: Chrześcijaństwo u schyłku starożytności. Studia Źródłoznawcze, pod red. T. Derdy, E. Wipszyckiej, t. 3, Kraków 2000.

Żurek A., Tajemnica Wcielenia w galijskiej literaturze V wieku na przykładzie Jana Kasjana, „Vox Patrum” 20 (2000), s. 267-280.

Żurek A., Życie i działalność Cezarego z Arles, w: Św. Cezary z Arles, oprac. i wybór tekstów A. Żurek, Kraków 2002, s. 7-84 (Ojcowie Żywi, 17). 